\title{
Environmental Assessment Using Integrated Risk Based Approach (IRBA) at Cahaya Kencana Landfill Site
}

\author{
Muhammad Sadiqul Iman and Ellina Sitepu Pandebesie
}

Department of Environmental Engineering, Institut Teknologi Sepuluh Nopember, Surabaya

e-mail: msiman.msi@gmail.com

\begin{abstract}
Cahaya Kencana landfill site located above the land belonging to the local government of Banjar District with land area 35,5 Ha, where used for Cahaya Kencana landfill 16,5 Ha, Kehati park 7,5 $\mathrm{Ha}$, the remaining unused land is 11,5 Ha. Cahaya Kencana landfill site has been implementing the sanitary landfill system since 2014 with the existing area of $8.089,73 \mathrm{~m}^{2}$ and the calculation results shows that sanitary landfill area can only use until the year 2021. So the goal that is to be achieved from this research is to evaluate the technical aspects and environment of Cahaya Kencana site with decision making tools. One of them through the assessment of environmental risk index or Integrated Risk Based Approach (IRBA). Risk Index (RI) assessment results using IRBA obtained 524,007 value with a category of moderate hazard evaluation, so that Cahaya Kencana site can be forwarded and rehabilitated into controlled landfill gradually. The strategy that needs to be done in the framework of Cahaya Kencana site is modifications of leachate treatment unit design.
\end{abstract}

Keywords-Leachate, Leachate Tratement Unit, Risk Index, Rehabilitation, Sanitary Landfill.

\section{INTRODUCTION}

$\mathrm{T}^{1}$ HE population growth in Banjar District is very rapid and increased especially in the capital of the district, Martapura subdistrict. This condition is also directly proportional to the increase in urban waste production. The increase in waste production led to increased area disposal. Cahaya Kencana landfill has been implementing the sanitary landfill system since 2014 until now with a condition that is almost full. Volume of garbage entered from the year 2014 to 2018 which is transported to the landfill reaches $376.621 \mathrm{~m}^{3}$ or an average of $206,37 \mathrm{~m}^{3} /$ day. Surely the problem requires environmental management as soon as possible, one of them by doing a risk assessment. It is necessary because lot of open dumping areas that are left abandoned without the proper mitigation [1].

Integrated Risk Based Approach (IRBA) was first used as a decision making tool in the location of Perungudi (PDG) and Kondungaiyur (KDG) in the city of Chennai, India where the calculation obtained the value of RI in the location of PDG of 569 and the location of the KDG 579 [2], [3]. Meanwhile, in the location of Eneka, Nigeria research obtained the value of RI 452,3 [4]. Other studies at Igbatoro landfill [5] have been found that the impacts include high health and environmental risks and the degree of silence on the impact of communities, where the risk index (RI) value gained is 571,58 . Rehabilitation landfill needs to be carried out due to soil pollution in the landfill area is usually polluted by leachate [6].
Cahaya Kencana landfill apparently has leachate contamination in the sanitary landfill area with the resistivity value of soil tainted in the range of $1,50-4,34 \Omega \mathrm{m}$ at a depth between 0,75 meters to 13 meters[7].

\section{MATERIAL AND METHODS}

\section{A. Description of the Studi Site}

The research location is located at Cahaya Kencana landfill at Lihung village, Karang Intan sub district, Banjar district, province South Kalimantan. Where for the retrieval of loose garbage samples is garbage truck that comes from Sekumpul street, while for the sampling of solid waste samples derived from sanitary landfill area. Location of Cahaya Kencana landfill located at $03^{\circ} 27^{\prime} 29.0^{\prime \prime}$ Southern Latitude (SL) and $114^{\circ} 55^{\prime} 28.2^{\prime \prime}$ East Longitude (EL). Figure 1. explains the location of this research.

\section{B. Risk Assessment}

Risk Index/ RI calculated with this formula [3]-[5]:

$$
R I=\sum_{i=1}^{n} W i S i
$$

Where:

$\mathrm{Wi}=$ Weightage of the with variable ranging from $0-1000$

$\mathrm{Si}=$ Sensitive index of the with variable ranging from $0-1$

RI $=$ Risk Index variable from $0-1000$

Risk Index (RI) can be used for classification of landfill sites to be closed or rehabilitated. A value of 0 indicates no or less danger, a value of 1 indicating the highest potential danger. The higher the value indicates greater risk to human health and the actions that must be taken immediately at the site of landfill. The next priority decreases with the total decrease in value. Lowest values indicate low sensitivas and small environmental impacts. Hazard-level evaluation criteria based on the risk index value of landfill can be seen in table 1. [2]-[5]. While device risk index assessment can be seen in table 2. [2]-[5], [8].

\section{RESULTS}

The measurement of maps with ArcGIS 10.2 software is derived data that the closest water source used in operational and maintenance activities in Cahaya Kencana landfill site is the river used for irrigation with the closest distance is 967 meters (Figure 2. (a)). Estimation of soil type in Cahaya Kencana landfill site is done by the approach of geological map of Banjar district in accordance with Banjar district spatial plan in year 2013-2032, where Cahaya Kencana landfill site is on the geological kwarter mud aluminum 


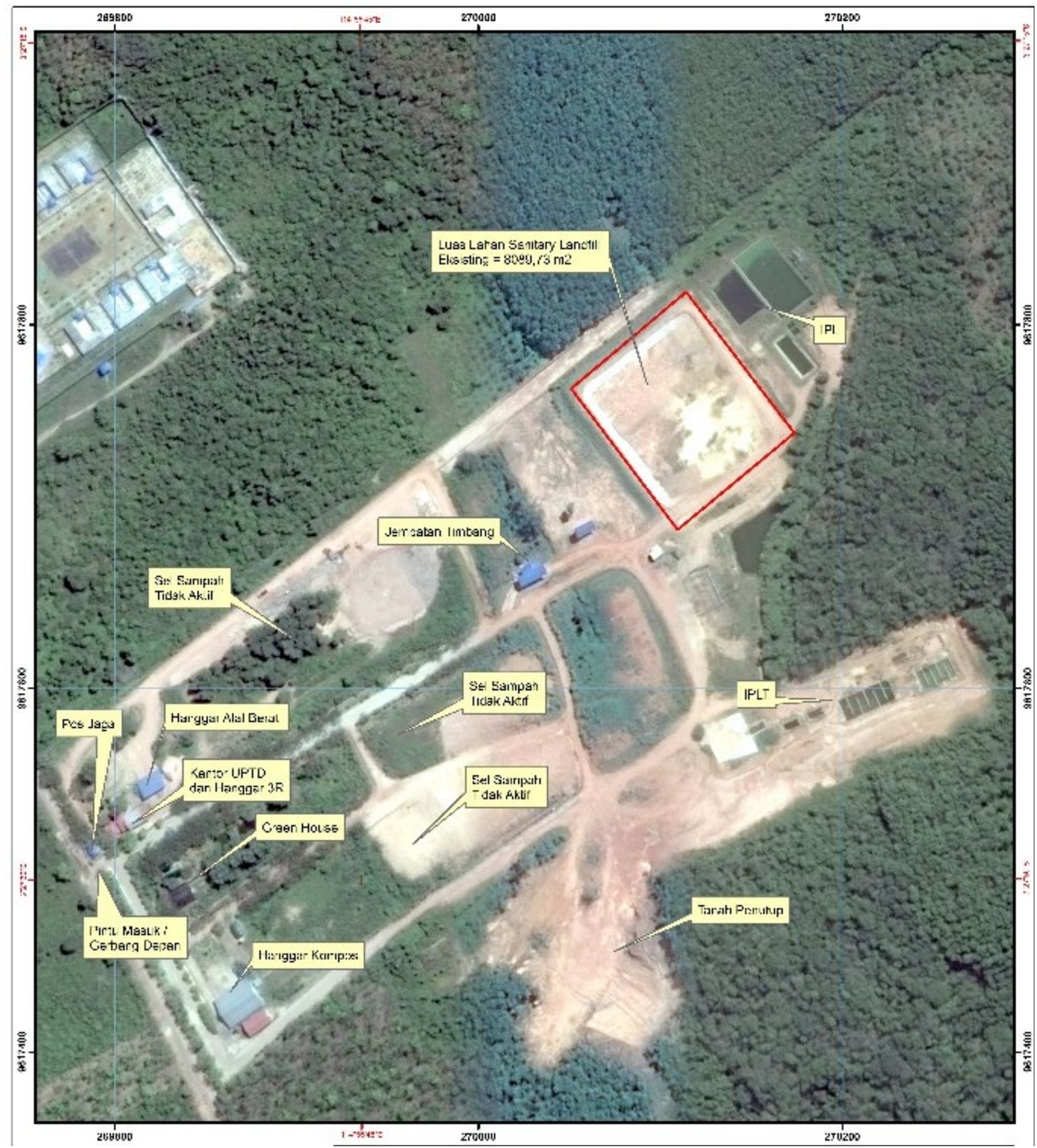

Figure 1. Cahaya Kencana Landfill Site Layout.

pebble sand, which can be assumed as a rough sand that has a permeability value between $1-0.01 \mathrm{~cm} / \mathrm{sec}$ [9]. Distance Cahaya Kencana site with conservation forest or critical habitats that is the education forest based on Banjar district spatial plan year 2013-2032 is 2.205 meters $(2,2 \mathrm{~km})$ (Figure 2. (b)). Closest airport to Cahaya Kencana site is Syamsudin Noor International Airport located in Banjarbaru City, with the airport distance is 19.082 meters (Figure 2. (c)). Surface water closest to Cahaya Kencana site is a river with a distance of about $1.154 \mathrm{~m}$ (Figure 2. (d)). Basic soil layer type of sanitary landfill in Cahaya Kencana site based on map of land type in Banjar district spatial plan year 2013-2032 ie alluvial land. The alluvial soil itself is formed from a young sedimentary material (aluvium), has an occric, Umbrik, hystics, or sulfide, a smoother texture of the flaky sand at a depth of $25-100 \mathrm{~cm}$ [10]. In the type of alluvial hydrik usually contains clay $>8 \%[10]$. The approach taken for the base layer of sanitary landfill in Cahaya Kencana site, from some research of characteristics of clay percentage in the alluvial soil is $>8 \%$. The resident area close to the location of Cahaya Kencana site is located in Padang Panjang Village, where based on measurements obtained by distance of $1.163 \mathrm{~m}$ (Figure 2. (e)). The capital of Banjar district is located in Martapura subdistrict and is the source of the major solid 
Table 1.

Criteria for Hazard Evaluation Based on the Risk Index

\begin{tabular}{|c|c|c|c|}
\hline No & Risk Index & Hazard Potential & Recommended Action \\
\hline 1 & $750-1000$ & Very High & $\begin{array}{l}\text { Close the dump with no more land filling in the area. Take remedial action to mitigate the } \\
\text { impacts }\end{array}$ \\
\hline 2 & $600-749$ & High & Close the dump with no more land filling in the area. Remediation is optional \\
\hline 3 & $450-599$ & Moderate & $\begin{array}{l}\text { Immediate rehabilitation of the dumpsite into } \\
\text { Sustainable Landfill }\end{array}$ \\
\hline 4 & $300-449$ & Low & Rehabilitate the dumpsite into Sustainable Landfill in a phased manner \\
\hline 5 & $<300$ & Very Low & Potential Site for future Landfill \\
\hline
\end{tabular}

Table 2 .

Tool of Rapid Risk Assessment for Dumpsite

\begin{tabular}{|c|c|c|c|c|c|c|}
\hline \multirow{2}{*}{ No } & \multirow{2}{*}{ Attribute } & \multirow{2}{*}{$\begin{array}{c}\text { Attribute } \\
\text { Weightage }\end{array}$} & \multicolumn{4}{|c|}{ Sensitivity Index } \\
\hline & & & $0,0-0,25$ & $0,25-0,5$ & $0,5-0,75$ & $0,75-1,0$ \\
\hline & I. Site Spesific Criteria & & & & & \\
\hline 1 & $\begin{array}{l}\text { Distance from nearest wáter supply } \\
\text { source }(\mathrm{m})\end{array}$ & 69 & $>5000$ & $2500-5000$ & $1000-2500$ & $<1000$ \\
\hline 2 & Depth of filling of waste $(\mathrm{m})$ & 64 & 3 & $3-10$ & $10-20$ & $>20$ \\
\hline 3 & Area of the dumpsite (Ha) & 61 & $<5$ & $5-10$ & $10-20$ & $>20$ \\
\hline 4 & Groundwater depth (m) & 54 & $>20$ & $10-20$ & $3-10$ & $<3$ \\
\hline 5 & $\begin{array}{l}\text { Permeability of soil } \\
\left(1 \times 10^{-6} \mathrm{~cm} / \mathrm{s}\right)\end{array}$ & 54 & $<0,1$ & $1-0,1$ & $1-10$ & $>10$ \\
\hline 6 & Groundwater quality & 50 & $\begin{array}{l}\text { Not a } \\
\text { concern }\end{array}$ & Potable & $\begin{array}{l}\text { Potable if no } \\
\text { alternative }\end{array}$ & Non-Potable \\
\hline 7 & $\begin{array}{l}\text { Distance to critical hábitats such as } \\
\text { wetlands and reserved forest }(\mathrm{km})\end{array}$ & 46 & $>25$ & $10-25$ & $5-10$ & $<5$ \\
\hline 8 & Distance to the nearest airport $(\mathrm{km})$ & 46 & $>20$ & $10-20$ & $5-10$ & $<5$ \\
\hline 9 & Distance from surface water (m) & 41 & $>8000$ & $1500-8000$ & $500-1500$ & $<500$ \\
\hline 10 & Type of underlying soil (\% clay) & 41 & $>50$ & $30-50$ & $15-30$ & $0-15$ \\
\hline 11 & Life of the site for future use (years) & 36 & $<5$ & $5-10$ & $10-20$ & $>20$ \\
\hline 12 & Type of waste (MSW/ HW) & 30 & $100 \% \mathrm{MSW}$ & $\begin{array}{l}75 \% \mathrm{MSW}, \\
25 \% \mathrm{HW}\end{array}$ & $\begin{array}{l}50 \% \mathrm{MSW} \\
50 \% \mathrm{HW}\end{array}$ & $>50 \% \mathrm{HW}$ \\
\hline 13 & Total quantity of waste at site (t) & 30 & $<10^{4}$ & $10^{4}-10^{5}$ & $10^{5}-10^{6}$ & $>10^{6}$ \\
\hline 14 & Quantity of waste disposed (t/day) & 24 & $<250$ & $250-500$ & $500-1000$ & $>1000$ \\
\hline 15 & $\begin{array}{l}\text { Distance to the nearest village in the } \\
\text { predominant wind }(\mathrm{m})\end{array}$ & 21 & $>1000$ & $600-1000$ & $300-600$ & $<300$ \\
\hline 16 & Flood proness (flood period in years) & 16 & $>100$ & $30-100$ & $10-30$ & $<10$ \\
\hline 17 & Annual rainfall at site $(\mathrm{cm} / \mathrm{y})$ & 11 & $<25$ & $25-125$ & $125-250$ & $>250$ \\
\hline 18 & Distance from the city $(\mathrm{km})$ & 7 & $>20$ & $10-20$ & $5-10$ & $<5$ \\
\hline 19 & Public acceptance & 7 & $\begin{array}{l}\text { No public } \\
\text { concerns }\end{array}$ & $\begin{array}{l}\text { Accepts } \\
\text { dump } \\
\text { rehabilitation }\end{array}$ & $\begin{array}{c}\text { Accepts } \\
\text { dump closure }\end{array}$ & $\begin{array}{l}\text { Accepts dump } \\
\text { closure and } \\
\text { remediation }\end{array}$ \\
\hline 20 & Ambient air quality $-\mathrm{CH}_{4}(\%)$ & 3 & $<0,01$ & $0,05-0,01$ & $0,05-0,1$ & $>0,1$ \\
\hline & II. Related to characteristics of waste a & psite & & & & \\
\hline 21 & Hazardous contents in waste $(\%)$ & 71 & $<10$ & $10-20$ & $20-30$ & $>30$ \\
\hline 22 & $\begin{array}{l}\text { Biodegradable fraction of waste at site } \\
(\%)\end{array}$ & 66 & $<10$ & $10-30$ & $30-60$ & $60-100$ \\
\hline 23 & Age of filling (years) & 58 & $>30$ & $20-30$ & $10-20$ & $<10$ \\
\hline 24 & $\begin{array}{l}\text { Moisture of waste at site (\%) } \\
\text { III. Related to of leachate quality }\end{array}$ & 26 & $<10$ & $10-20$ & $20-40$ & $>40$ \\
\hline 25 & BOD of leachate $(\mathrm{mg} / \mathrm{L})$ & 36 & $<30$ & $30-60$ & $60-100$ & $>100$ \\
\hline 26 & COD of leachate $(\mathrm{mg} / \mathrm{L})$ & 19 & $<250$ & $250-350$ & $350-500$ & $>500$ \\
\hline 27 & TDS of leachate $(\mathrm{mg} / \mathrm{L})$ & 13 & $<2100$ & $2100-3000$ & $3000-4000$ & $>4000$ \\
\hline
\end{tabular}

waste source dumped into Cahaya Kencana site, it is known that the city distance to landfill is $6.840 \mathrm{~m}(6,8 \mathrm{~km})$ (Fig. 2. (f)).

Life of the site for the future use calculation is obtained from population projection data from year 2018-2028 by using least square method with value of $\mathrm{R}^{2}=0,9991$ as well as standard deviation of 18.833 . Loose waste composition measured dominated by 3 types of garbage composition of food remnants + leaves (organic) $51,12 \%$, plastic $22,44 \%$ and diapers \& sanitary pads $8,83 \%$ and the value of loose waste density is $216,68 \mathrm{~kg} / \mathrm{m}^{3}$. Meanwhile solid garbage composition measured also dominated by 3 types of garbage composition that is food remnants + leaves (organic) 45,86\%, plastic $29,94 \%$ and diapers \& sanitary pads $11,93 \%$ and obtained the value of solid waste density of $724,00 \mathrm{~kg} / \mathrm{m}^{3}$.
Accumulation rate uses 2,75 liters/person/day according to the major city classification [11].

The level of garbage in sanitary landfill in Cahaya Kencana site is 10 meters high with land area of $8089,73 \mathrm{~m}^{2}$. The results of future landfill age are obtained 1 year or until year 2021. While based on the results of the community kuisoner, it is obtained that the average community as much as $60 \%$ received the existence and rehabilitation of open waste landfill.

Laboratory test results obtained leachate results for the BOD parameter has value of $210 \mathrm{mg} / \mathrm{L}, \mathrm{COD}$ has value of $501,73 \mathrm{mg} / \mathrm{L}$, and the TDS has value of $2.254 \mathrm{mg} / \mathrm{L}$. Solid waste moisture content is $58,23 \%$. Quality of water well in Cahaya Kencana site can not be used as a source of drinking water. Because the parameter of hardness water has a value of $1444,20 \mathrm{mg} / \mathrm{L}$, E. Coli as much as $1,3 \times 10^{3}$ amount $/ 100 \mathrm{~mL}$ 


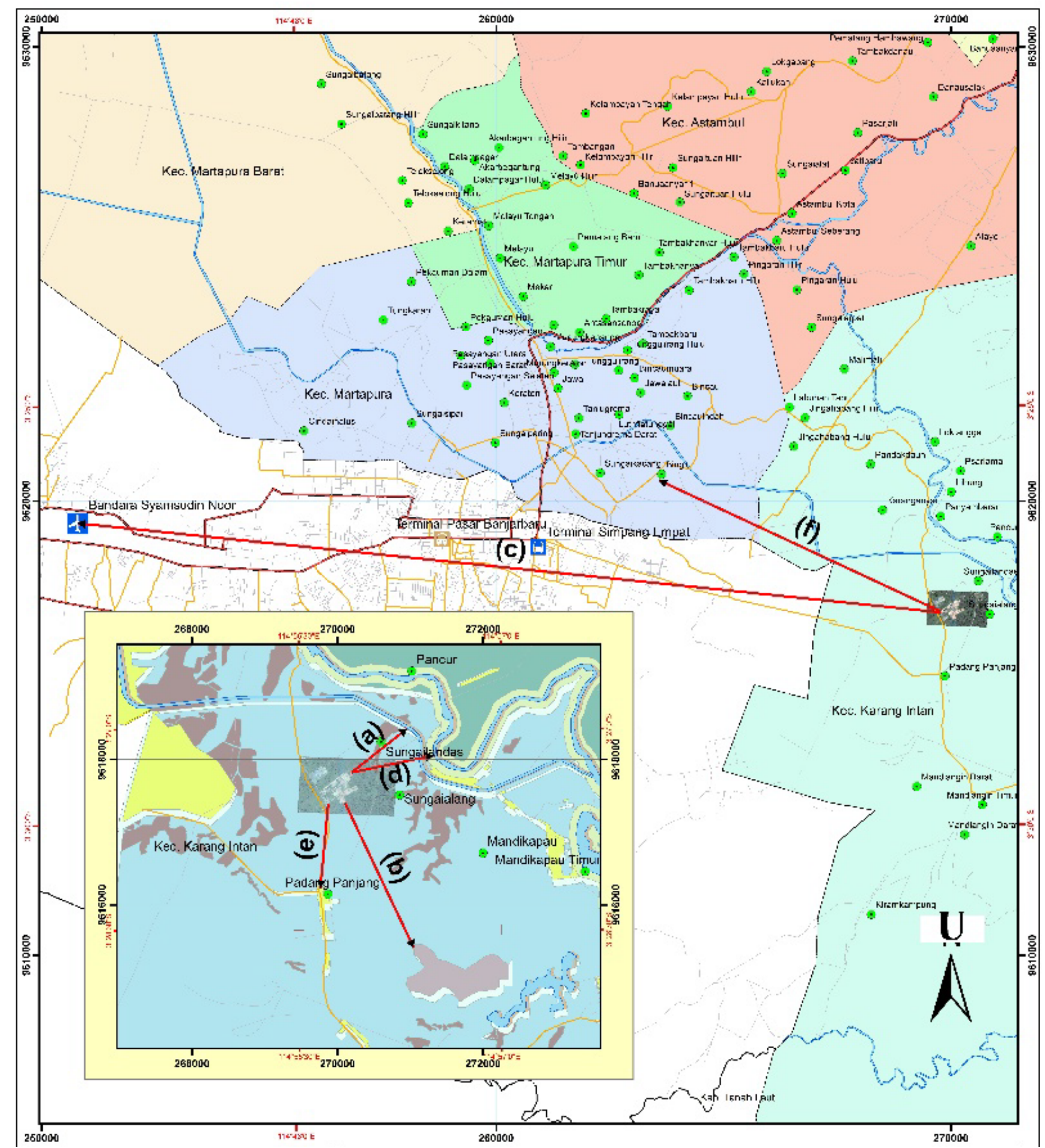

Figure 2. Measuring IRBA Parameter with Software ArcGIS 10.2.

and Coliform as much as $1,1 \times 10^{4}$ amount/100mL which exceeds the quality of Permenkes No. 492/Menkes/Per/IV/2010 about the requirements of drinking water quality.

Risk Index (RI) assessment results use IRBA, as can be seen in table 3. obtained a value of 524,007 with a category of moderate hazard evaluation, so that Cahaya Kencana site can be forwarded and rehabilitated into controlled landfill gradually. One important aspect of this rehabilitation landfill process is leachate treatment unit. Based on the results of comparison of leachate treatment unit existing with the calculation result then obtained data according to table 4 .

Through Table 4 . we can perform optimal processing efficiency on each pond, with a modification design. For example for anaerobic pond lenght, the comparison is $1 / 5$, so the existing pond can be blocked into 5 parts. So that leachate can be processed optimally according to the hydraulic retention time (HRT). This also applies to each other pond with the addition of the connecting floodgates of each partition. This water door can be opened at the time of the 
Table 3.

Risk Index Worksheet for Cahaya Kencana Dumpsite

\begin{tabular}{|c|c|c|c|c|c|}
\hline No & Attribute & $\begin{array}{l}\text { Attribute } \\
\text { Weightage }\end{array}$ & $\begin{array}{c}\text { Attribute } \\
\text { Measurement }\end{array}$ & SI & Score \\
\hline 1 & Distance from nearest wáter supply source (m) & 69 & 967 & 0,750 & 51,750 \\
\hline 2 & Depth of filling of waste $(\mathrm{m})$ & 64 & 10 & 0,500 & 32,000 \\
\hline 3 & Area of the dumpsite $(\mathrm{Ha})$ & 61 & 16,5 & 0,663 & 40,413 \\
\hline 4 & Groundwater depth (m) & 54 & 3,78 & 0,528 & 28,504 \\
\hline 5 & $\begin{array}{l}\text { Permeability of soil } \\
\left(1 \times 10^{-6} \mathrm{~cm} / \mathrm{s}\right)\end{array}$ & 54 & 1 & 0,500 & 27,000 \\
\hline 6 & Groundwater quality & 50 & $\begin{array}{c}\text { Groundwater quality from laboratory } \\
\text { test results, not a concern }\end{array}$ & 0,000 & 0,000 \\
\hline 7 & $\begin{array}{l}\text { Distance to critical hábitats such as wetlands } \\
\text { and reserved forest }(\mathrm{km})\end{array}$ & 46 & ( & 0,860 & 39,560 \\
\hline 8 & Distance to the nearest airport $(\mathrm{km})$ & 46 & 19 & 0,475 & 21,850 \\
\hline 9 & Distance from surface water $(\mathrm{m})$ & 41 & 1154 & 0,664 & 27,204 \\
\hline 10 & Type of underlying soil (\% clay) & 41 & 8 & 0,883 & 36,217 \\
\hline 11 & Life of the site for future use (years) & 36 & 2 & 0,100 & 3,600 \\
\hline 12 & Type of waste (MSW/ HW) & 30 & 69,40 & 0,847 & 25,410 \\
\hline 13 & Total quantity of waste at site $(\mathrm{t})$ & 30 & 186485 & 0,524 & 15,721 \\
\hline 14 & Quantity of waste disposed (t/day) & 24 & 102,18 & 0,102 & 2,452 \\
\hline 15 & $\begin{array}{l}\text { Distance to the nearest village in the } \\
\text { predominant wind }(\mathrm{m})\end{array}$ & 21 & 1163 & 0,041 & 0,856 \\
\hline 16 & Flood proness (flood period in years) & 16 & 200 & 0,000 & 0,000 \\
\hline 17 & Annual rainfall at site $(\mathrm{cm} / \mathrm{y})$ & 11 & 247 & 0,744 & 8,184 \\
\hline 18 & Distance from the city $(\mathrm{km})$ & 7 & 6,8 & 0,590 & 4,130 \\
\hline 19 & Public acceptance & 7 & Accepts dump rehabilitation & 0,325 & 2,275 \\
\hline 20 & Ambient air quality $-\mathrm{CH}_{4}(\%)$ & 3 & 5 & 0,500 & 1,500 \\
\hline 21 & Hazardous contents in waste $(\%)$ & 71 & 1,48 & 0,037 & 2,627 \\
\hline 22 & Biodegradable fraction of waste at site $(\%)$ & 66 & 11,06 & 0,263 & 17,375 \\
\hline 23 & Age of filling (years) & 58 & 8 & 0,950 & 55,100 \\
\hline 24 & Moisture of waste at site (\%) & 26 & 58,23 & 0,826 & 21,475 \\
\hline 25 & BOD of leachate $(\mathrm{mg} / \mathrm{L})$ & 36 & 210 & 1,000 & 36,000 \\
\hline 26 & COD of leachate $(\mathrm{mg} / \mathrm{L})$ & 19 & 501,73 & 1,000 & 19,000 \\
\hline \multirow[t]{3}{*}{27} & TDS of leachate (mg/L) & 13 & 2254 & 0,293 & 3,806 \\
\hline & & & & RI & 524,007 \\
\hline & & & & $\begin{array}{c}\text { Potential } \\
\text { Hazard }\end{array}$ & Moderate \\
\hline
\end{tabular}

Table 4.

Dimensions Comparison Between Existing and Calculation of Leachate Treatment Unit

\begin{tabular}{|c|c|c|c|c|c|c|c|c|c|c|c|}
\hline \multirow[t]{2}{*}{ 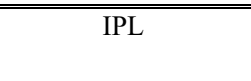 } & \multirow{2}{*}{$\begin{array}{l}\text { Discharge } \\
\text { L/second }\end{array}$} & \multirow{2}{*}{$\begin{array}{c}\text { Discharge } \\
\mathrm{m}^{3} / \text { day }\end{array}$} & \multirow{2}{*}{$\begin{array}{l}\text { HRT } \\
\text { (day) }\end{array}$} & \multirow{2}{*}{$\begin{array}{c}\text { HRT } \\
\text { (hours) }\end{array}$} & \multirow{2}{*}{$\begin{array}{c}\text { Depth (h) } \\
\text { (m) }\end{array}$} & \multicolumn{2}{|c|}{ "Calculate } & \multicolumn{2}{|c|}{ Existing } & \multicolumn{2}{|c|}{ Comparison } \\
\hline & & & & & & $\mathrm{L}(\mathrm{m})$ & W (m) & $\mathrm{L}(\mathrm{m})$ & W (m) & $\mathrm{L}(\mathrm{m})$ & $\mathrm{W}(\mathrm{m})$ \\
\hline Collector Unit & 0,018 & 1,550 & 0,042 & 1 & 0,500 & 1 & 0,2 & 1 & 1 & 1 & $1 / 5$ \\
\hline Anaerobic Pond & 0,018 & 1,550 & 18,700 & & 3,000 & 6 & 2 & 30 & 16 & $1 / 5$ & $1 / 8$ \\
\hline Fakultative Pond & 0,018 & 1,550 & 37,400 & & 2,000 & 9 & 3 & 45 & 24 & $1 / 5$ & $1 / 8$ \\
\hline Biofilter (2 unit) & 0,018 & 1,550 & 0,197 & 9 & 1,500 & 1 & 0,3 & 7 & 5 & $1 / 6$ & 0 \\
\hline Constructed Wetland & 0,018 & 1,550 & 3,000 & & 0,500 & 6 & 4 & 26 & 10 & $1 / 4$ & $2 / 5$ \\
\hline
\end{tabular}

leachate discharge that enters exceeds the leachate discharge from calculation results.

\section{CONCLUSION}

Risk Index (RI) assessment results using IRBA obtained 524,007 value with a category of moderate hazard evaluation, so that Cahaya Kencana landfill site can be forwarded and rehabilitated into controlled landfill gradually. Leachate treatment unit can be design modification, so that the resulting effluent will be in accordance with the quality standards that have been set.

\section{REFERENCES}

[1] N. I. M. Pauzi, M. S. M. Radhi, and H. Omar, "Risk assessment predictions of open dumping area after closure using Monte Carlo simulation," 2017, doi: doi.org/10.1063/1.5005672.

[2] K. Joseph, R. Nagendran, K. Thanasekaran, C. Visvanathan, and W. Hogland, "Dumpsite Rehabilitation Manual," Chennai, India, 2005. [Online]. Available: https://www.elaw.org/system/files/Dumpsite Rehabilitation Manual.pdf.
[3] K. Joseph, S. Esakku, R. Nagendran, and C. Visvanathan, "A decision making tool for dumpsite rehabilitation in developing countries," in Proc. Sardinia, Eleventh International Waste Management and Landfill Symposium, 2005.

[4] S. O. Abah and E. I. Ohimain, "Assessment of Dumpsite Rehabilitation Potential Using the Integrated Risk Based Approach: a Case Study of Eneka, Nigeria," World Appl. Sci. J., vol. 8, no. 4, pp. 436-442, 2010, [Online]. Available: https://idosi.org/wasj/wasj8(4)10/8.pdf.

[5] O. O. Ojuri, F. O. Ayodele, and O. E. Oluwatuyi, "Risk assessment and rehabilitation potential of a millennium city dumpsite in Sub-Saharan Africa," Waste Manag., pp. 621-628, 2018, doi: 10.1016/j.wasman.2018.03.002.

[6] L. Darmayanti, M. Yusa, and E. RA, "Identifikasi tanah tercemar lindi tempat pembuangan akhir sampah muara fajar dengan metode geolistrik," Bumi Lestari J. Environ., vol. 11, no. 2, pp. 371-378, 2011, [Online]. https://ojs.unud.ac.id/index.php/blje/article/view/159.

[7] D. Prastika, P. S. C. Wahyono, and T. N. Manik, "Penentuan sebaran dan kandungan unsur kimia kontaminasi limbah cair bawah permukaan di tpa cahaya kencana, Kabupaten Banjar," J. Fis. Flux J. Ilm. Fis FMIPA Univ. Lambung Mangkurat, vol. 12, no. 2, pp. 140-149, 2015, doi: $10.20527 /$ flux.v12i2.2614.

[8] Kementrian Pekerjaan Umum Republik Indonesia, Peraturan menteri pekerjaan uтum no.3/PRT/M/2013 tahun 2013 tentang penyelenggaraan prasarana dan sarana persampahan dalam penanganan sampah rumah tangga dan sampah sejenis sampah rumah 
The $1^{\text {st }}$ International Conference on Business and Engineering Management (IConBEM 2020)

February $1^{\text {st }} 2020$, Institut Teknologi Sepuluh Nopember, Surabaya, Indonesia

tangga. 2013.

[9] B. M. Das, Mekanika Tanah (Prinsip-Prinsip Rekayasa Geoteknis) Jilid 1, Terjemahan. Surabaya: Erlangga, 1988.

[10]D. S. S., S. Ritung, M. Anda, S. Sukarman, E. Suryani, and R. E. Subandiono, Petunjuk Teknis Klasifikasi Tanah Nasional. Bogor: Balai Besar Penelitian dan Pengembangan Sumberdaya Lahan Pertanian, Badan Penelitian dan Pengembangan Pertanian, 2014.

[11]M. S. Amien, Diseminasi dan Sosialisasi Keteknikan Bidang PLP: Materi I Bidang Sampah. Jakarta, Indonesia: Direktorat Pengembangan Penyehatan Lingkungan Permukiman Direktorat Jenderal Cipta Karya Kementrian Pekerjaan Umum, 2012. 